\title{
Irrigation Water Saving of Date Palm Tree Plantations Using Soil Amendments in UAE
}

\author{
Mohamed Aly Badawi
}

\section{Soils Water and Environment Research Institute, ARC, Giza Egypt \& G.M., Emirates \\ Biofertilizers Factory}

dr_badawi22@hotmail.com

\begin{abstract}
Date palm (Phoenix dactylifera) tolerates relatively harsh climatic and soil condition in Arab countries. The annual total irrigation water requirements in the Arab regions is ranging from 73.0 to $95\left(\mathrm{~m}^{3} /\right.$ tree). Approximately $70-80$ per cent of global freshwater consumption is used in the agricultural sector, yet water use efficiency in many countries is below 50 per cent. Water saving amendments, are a natural soil mixes and has been developed and used to reduce the amount of water needed in irrigation for date palm farms, to maintain vigorous plants growth. When mixed in the soil, the material can retain great amounts of water per $\mathrm{kg}$ of product. When the soil dries, the product will release its water to the plant. Water saving amendments acts as a water reservoir, especially during periods of drought and the stored water is released to the plants. Using water saving amendments not only save water but also, improve the soil physical properties e.g. water holding capacity (WHC) and cation exchange capacity (CEC) of the treated soil. In this experiment we used three natural different water conservative materials to study its effects on saving irrigation water under date palm plantations. Three different levels of water saving materials e,g., compost (C), Bio Char (BC) and water saving (WS) product from Emirates Biofertilizers Factory products were used at four different levels e.g. 5, 10,15 and $20 \mathrm{~kg}$ per date palm tree against control of 7 years old trees grown in Al Salamat research station, Al Ain UAE. The plants tested were, Date palm trees. After two years of testing, we found that water saving amendments can save more than $40 \%$ of irrigation water. Our results recommended that, addition of $15 \mathrm{~kg} /$ date palm tree can reduce the water needed for irrigation by $40 \%$. In this research paper, we focused mainly on introducing a natural means of managing irrigation water through soil conditioning, using water saving amendments to be incorporated in soil around the trees to prevent water losses by run off, evaporation and infiltration and to improve the soil physical, chemical and biological properties. Economic Values of water saved are studied
\end{abstract}

KEY WORDS: Compost, Biochar, Water Saver, Irrigation, and Date palm trees. 


\section{INTRODUCTION}

Today, some 2.8 billion people live in water-scarce areas, but by 2030, it is expected that about half of the world's population will live in water stressed areas. World agriculture faces an enormous challenge over the next 40 years: to produce almost 50\% more food up to 2030 and double production by 2050 . This will probably have to be achieved with less water, mainly because of pressure from growing urbanization, industrialization and the negative impact of climate change, (FAO, 2012 and Ahmed et al. 2012.]

An increase in $\mathrm{C}$ content of the soil increases aggregation, decreases bulk density, increases water holding capacity, (Vengadaramana \& Jashothan, 2012) .Date palm trees (DPT) in the UAE generate around 600000 tons of date fronds which is an abundantly available agricultural waste and small percentage is economically used and recycled, and same problems exists in many date producing countries. DPT, are cultivated in arid and semi-arid regions and can thrive in long and hot summers, low rainfall and very low relative humidity (WHO, 2010). About 105 million trees are available around the Arab world covering over a million hectares. The UAE has the largest number of date palm trees in the Arab world, there are about 42 million date palm trees. Each tree generates about 15 kilograms $(\mathrm{kg})$ of waste biomass annually, totaling 600 million $\mathrm{kg}$ of green waste. Converting date palm waste into soil amendments can reduce carbon dioxide $\left(\mathrm{CO}_{2}\right)$ and methane $\left(\mathrm{CH}_{4}\right)$ emissions generated by the natural decomposition or through burning of the waste. $\mathrm{UAE}$ is one of the largest producers of date fruits with more than 42 million date palm trees and an annual production rate of 770,000 tons of date fruits (MOEW, 2015 \& Zainab et al. 2015 and Qasim, et al.2015 \& Badawi, 2020 ).

The United Arab Emirates (UAE) h as sandy soil with very low water and nutrient holding capacities. In these conditions, date palm is considered one of the most resilient crops in the region.

Over the years, with rising temperatures and scarce precipitation, there have been calls for new ways to conserve water, improve soil properties and prevent nutrient loss to achieve future food and nutrition security.

Two major natural resource concerns of this century are climate change and water (quality and quantity). Soil texture and organic matter content are the key components that determine soil water holding capacity (WHC). Water holding capacity of soils is controlled primarily by: (i) the number of pores and pore-size distribution of soils; and (ii) the specific surface area soils. Because of increased aggregation, total pore space is increased (FAO, 2012 and Ahmed et al. 2012and Sohi, 
et al. 2010, Wallace, 2000 and Claoston et al. 2014). Furthermore, as a result of decreased bulk density, the pore-size distribution is altered and the relative number of small pores increases, especially for coarse textured soils (Sohi et al. 2010). Sandy soils have much less surface area than clayey soils and, thus, retain much less water at higher tensions. However, with the addition of organic matter, specific surface area increases resulting in increased WHC at higher tensions [Sohi et al. 2010 and Barrow, 2012). Soil "holds" water available for crop use, retaining it against the pull of gravity. And this is one of the most important physical facts for agriculture. If the soil did not hold water. Soil texture and organic matter are the key components that determine soil water holding capacity. In one study, after 32 years, AWC increased by $23 \%$ in NT vs. CT where residue was retained under both systems. This increase was correlated to soil organic matter (SOM) increases (Mobius-Clune et al., 2008). Soil organic matter (SOM) increased 102\% under NT in the surface 20 centimeters $(\mathrm{cm})$. In another study, "because of the changing nature of the soil matrix (mineral-dominated to organic carbon dominated surfaces), the change in AWC ranges from about 2.5 to $5 \%$ per $1.0 \%$ change in organic carbon in soils containing less than $2.5 \%$ organic carbon and less than 40\% clay" (Olness and Archer, 2005). The increase in amount of SOM in any soil is highly correlated to the increase in AWC. In all textural classes studied (sand, silt loam, silty clay loam), increasing SOM from 1 to 3 percent for the sand, and 2 to 4 percent for the silt loam and silty clay loam classes, increased AWC by 73, 45, and 47 percent respectively.

This paper demonstrates that in a business-as-usual scenario, water consumption in agriculture would almost double. current water use trends are not sustainable in the face of population growth and climate change [Donnelly and Cooley, 2015]. Both economic development and security are placed at risk by poor water management. Groundwater has provided great benefits to agriculture irrigation in semi-arid countries, but its intensive use beyond recharge in certain regions has depleted resources and generated significant negative environmental externalities.

During seasons of drought and water scarcity, the other inefficiencies of irrigation and soil management make already difficult times for farmers even worse, (MOEW , 2015 and Badawi, 2019 AB). Since water is essential to grow food, a drought situation can pose major problems for agriculture. Hence, farmers often face extreme poverty in drought-prone areas. Efficient water use techniques are very important in the face of climate change, (Sohi et al. 2010, Clawston et al. 2014, Barrow 2012 and Khanmohamadi et al. 2015) 
In The Kingdom of Saudi Arabia ,KSA, (Abdulrasoul et al. 2017). studied the irrigation water requirements for date palm trees in several areas. The annual total irrigation water requirements ( $\mathrm{m}$ 3 /tree) in these regions are $95,73.4,73,89,86,85.7,80,85 \mathrm{~m} 3$, respectively as the radius of shaded area per tree is $3.5 \mathrm{~m}$. Each soil type has a different capability to hold moisture based on soil depth, soil texture (ratios of various soil particle sizes), soil structure (soil porosity) and soil water tension. A combination of these elements determines the amount of water available to the plant. Soil type may vary within the root zone, so it is important to know crop root depth and the soil type throughout the root zone. [Hansen, et al. 1979, Russel, 1980, Wan et al. 2007 and Zhang et al. 2017).

Soil acts as a water reservoir between irrigations or rains. Soil is also a nutrient reservoir, and it mechanically supports and stabilizes plants. Each soil type has a different capability to hold moisture based on soil depth, soil texture (ratios of various soil particle sizes), soil structure (soil porosity) and soil water tension. A combination of these elements determines the amount of water available to the plant.

Biochar is a solid product produced from thermal conversion of unstable carbon-enriched materials into stable carbon-enriched charred materials that can be incorporated into the soils as a mean for agronomic or environmental management. Biochar can be produced out of a long list of feedstock. The composition of biochar (content in carbon, nitrogen, potassium, calcium, etc) is directly related on the feedstock used and the duration and temperature of pyrolysis.

Biochar has been produced with a range of $\mathrm{pH}$ values between 4 and 12, dependent upon the feedstock and pyrolysis temperature [8]. Generally, low pyrolysis temperatures $\left(<400^{\circ} \mathrm{C}\right)$ yield acidic biochar, while increasing pyrolysis temperatures produce alkaline biochar. Once incorporated to the soil, surface oxidation occurs due to reactions of water, $\mathrm{O}_{2}$ and various soil agents (Lehmaan, 2007 and Cheng et al. 2006). The cation exchange capacity (CEC) of fresh biochar is typically very low, but increases with time as the biochar ages in the presence of $\mathrm{O} 2$ and water (Lehmman 2007, Cheng et al. 2008 and Liang et al. 2006)

Previous analysis have shown that it is feasible to prepare biochar with relatively high BET surface areas from date palm fronds, which is favorable for microbial communities to grow and therefore enhancing fertility of the soils,. Biochar enhances soils. By converting agricultural waste into a powerful soil enhancer that holds carbon and makes soils more fertile, we can boost food security, 
discourage deforestation and preserve cropland diversity (Yu et al. 2013, Muhamad et al. 2018, Badawi 2019, a) and Pokharel et al. 2020).

Biomass produced from date palm trees can't be composted easily in normal composting process due to its high content of lignocellulose compound, while the biochar production can be the option to generate both energy and soil conditioner for the improvement of sandy soil under the gulf countries severe climate. Compost, biochar and water saver are stable biologically produced carbon sources that can be added to soil. It processes agricultural waste into a soil enhancer that improves soil fertility, saves water, helps to mitigate greenhouse gas (GHG) emissions and fight global warming.

\section{MATERIALS AND METHODS}

A. Soils, sandy soil used in this study, located in Al Ain, Abu Dhabi - UAE.

B. Irrigation water used was underground water wells. Analysis of soil and irrigation water, are presented in table (1).

C. Water Saving amendments were produced at Emirate Bio Fertilizer Factory from natural materials e.g. Composted animal manure and biochar from the pyrolysis of dry date palm trees frond treated at $350^{\circ} \mathrm{C}$. While water saver product is produced at EBFF from clay minerals, organic matter, Gypsum and Amorphous Silica. Analysis of water saver used are in Table (2).

Table (1) Soil and irrigation water analysis used in experiment

\begin{tabular}{|l|l|l|l|l|l|l|l|l|l|l|l|}
\hline Samples & \multicolumn{9}{|c|}{ Cations } & \multicolumn{4}{l|}{ Anions } \\
\cline { 2 - 13 } & $\mathrm{pH}$ & $\mathrm{EC}$ & $\mathrm{CaCO}_{3}$ & $\mathrm{Ca}$ & $\mathrm{Mg}$ & $\mathrm{Na}$ & $\mathrm{K}$ & $\mathrm{Cl}$ & $\mathrm{CO}_{3}$ & $\mathrm{HCO}_{3}$ & $\mathrm{SO} 4$ \\
\hline Soil & 7.30 & 21.2 & 26.95 & 27.6 & 58.3 & 124 & 3.8 & 146 & 0.0 & 2.5 & 42.9 \\
\hline Water & 7.50 & 13.6 & --- & 490 & 462 & 1393 & 46 & 3053 & 0.0 & 91.5 & 2640 \\
\hline
\end{tabular}

Preparation of compost (C:

Mixed cow manure and chicken manures collected from dairy and chicken farms in Al Ain, AD emirates are composted in windrow systems, with a proper conditions of aeration, moisture and adjusting for one month till maturation, and heat treated properly, and the analysis of end product are depicted in table (2).

Preparation of biochar (BC) Date palm tree waste leaves, was collected from al Ain City, UAE. The waste was dried in air under sunshine and then chopped to small pieces. Pyrolysis of the 
processed date palm waste was carried out in a closed stainless-steel container 2001 capacity, at 350 0C were maintained for $4 \mathrm{~h}$ under a limited supply of air. Feedstock samples were pyrolyzed to the desired temperature at the rate of $5 \circ \mathrm{C} \mathrm{min}-1$. The biochar produced $(25 \% \mathrm{~W} / \mathrm{W})$ were left to cool inside the furnace overnight, analysis of biochar are in Table (3).

Preparation of water saver (WS): Water saver product (WS) is a special mix of clay minerals, organic substances, gypsum and amorphous silica. Analysis of WS are in Table (3).

Table (2) Analysis of water saving amendment products used in experiment.

\begin{tabular}{|l|c|c|c|c|}
\hline \multirow{2}{*}{ Parameter } & \multicolumn{4}{|c|}{ Values } \\
\cline { 2 - 5 } & Sandy soil & Compost & Biochar & Water saver \\
\hline Moisture (\%) & 15.0 & 12.0 & 12.2 & 12.1 \\
\hline Organic matter (\%) & 0.22 & 42.0 & 75.0 & 40.0 \\
\hline pH value & 7.73 & 7.2 & 6.8 & 7.0 \\
\hline EC mmoh/cm & 0.51 & 9.2 & 6.4 & 4.5 \\
\hline Total nitrogen (\%) & 0.12 & 1.6 & 1.12 & 1.0 \\
\hline Total phosphorus (\%) & 0.09 & 1.2 & 0.9 & 0.5 \\
\hline Total potassium (\%) & 0.9 & 1.2 & 1.4 & 0.5 \\
\hline Total sulfur (\%) & 0.3 & 0.8 & 0.6 & 5.0 \\
\hline Water holding capacity L/Kg & 0.160 & 0.8 & 1.5 & 25.0 \\
\hline Specific gravity, (kg / l) & 2.65 & 0.6 & 0.3 & 0.4 \\
\hline Cation Exchange capacity (meq/100 gm) & 7.6 & 36.0 & 48.2 & 120 \\
\hline
\end{tabular}

\section{METHODS:}

10 identical date palm trees of 7 years old are used in each treatment for this experiment of the month of October 2016/2017 and 2017/2018 at Al Salamat research station. Treatments were Control, $5 \mathrm{~kg} /$ tree, $10 \mathrm{~kg} /$ tree, $15 \mathrm{~kg} /$ tree and $20 \mathrm{~kg} /$ tree of materials, and it was mixed in the tree bits around the tree.

Irrigation was scheduled every 6 days in summer months and every 16 days in winter months and every 8 days in moderate months.

1- Irrigation water was monitored and water consumption was recorded, using water meter.

2- Soil samples were taking for analysis of water content, and samples dried at $105^{\circ} \mathrm{C}$ for 24 hours. 
3- Chemical analysis of soil, water, compost, biochar and water saver, followed the standard methods protocol as per, AOAC 1975 \& Black et al. 1982)

4- Water holding capability for retention of water was measured in a separate experiment in 100 grams of materials and soil mix samples were saturated with water and incubated for 24 hours, then weight of water drained and water retained are recorded. Then calculated WHC of the tested materials as in table (3).

Table (3) values of water holding capacity and cation exchange capacity of material used in the experiment.

\begin{tabular}{|l|c|c|}
\hline Material & $\begin{array}{c}\text { Water Holding capacity } \\
1 / \mathrm{kg} \text { of materials }\end{array}$ & $\begin{array}{c}\text { Cation Exchange Capacity } \\
\text { Meq/100g }\end{array}$ \\
\hline Sand & 0.16 & 3.5 \\
\hline Compost & 3.0 & 85.0 \\
\hline Biochar & 5.0 & 120 \\
\hline Water saver & 25.0 & 180.0 \\
\hline
\end{tabular}

CEC, an abbreviation for Cation Exchange Capacity, refers to the amount of negative charges available on the surface of soil particles. It gives an indication of the potential of the soil to hold plant nutrients, by estimating the capacity of the soil to retain cations, which are positively-charged substances. Th CEC was measured following the (Black et al. 1982).

Periodical samples were taken after one week, 30 days, 60 days, 90 days and at the end of experiment at 180 days. Soil samples were prepared and tested according to protocol followed by Total bacterial counts CFU, was measured using nutrient agar media, according to (Difco, 1985), while potato dextrose media was used to measure the total fungi in respective order.

Each mixture used in this study was saturated with water by following the procedure found in (Chapman and Pratt, 1961) to establish sample's water holding capacity. Water was slowly applied to each mixture container, while gently agitating, until excess water was observed. The mixtures were then allowed to sit for $24 \mathrm{~h}$ to assure homogeneity of water content throughout the sample. After that, the mixtures were drained by gravity for another $24 \mathrm{~h}$ through a coffee filter. Three 90 $\mathrm{mL}$ stainless steel containers were then tared, filled to two third full, and massed using a 0.01-g digital balance to determine wet mass. The samples were then dried at $110^{\circ} \mathrm{C}$ for $24 \mathrm{~h}$ using a 
convection oven and remassed to determine the dry mass. The results yielded the amount of water being held by each mixture.

\section{RESULTS \& DISCUSSIONS}

The results obtained in this study showed that incremental increase in percent water holding capacity normalized to percent biochar amendment.

addition of water saving amendments, e.g. Compost $@$, Biochar BC and water saver product (WS) improved water holding capacity and reduced irrigation water requirements for date palm trees in all treatments against control. It gives an indication of the potential of the soil to hold plant nutrients, by estimating the capacity of the soil to retain cations, which are positively-charged substances. Evaluation of water holding capacity, WHC and water saving amendment in sandy soil over time as affected by addition of water saving amendments are depicted in table (7-8-9). Increasing the ratio of water saving amendments reduced the water losses and increased the water retention to be used by date palm trees.

Table (7) showed the effect of adding compost to date palm trees grown in sandy soils. It is clear that irrigation water requirements decreased with increasing amount per tree from $5 \mathrm{~kg} /$ tree to 20 $\mathrm{kg} / \mathrm{tree}$. The irrigation water decreased from $70.5 \mathrm{~m}^{3}$ to $63.4 \mathrm{~m}^{3} /$ tree per year.

Table (4) Average irrigation water per date palm tree of 7 years old, during different seasons and water saved percent when using compost soil amendment in Al Ain for two years.

\begin{tabular}{|l|c|c|c|c|c|}
\hline \multirow{2}{*}{ Treatment } & \multicolumn{5}{|c|}{ Compost } \\
\cline { 2 - 6 } & $\begin{array}{c}\text { Summer } \\
\text { months (L) }\end{array}$ & $\begin{array}{c}\text { Winter } \\
\text { months (L) }\end{array}$ & $\begin{array}{c}\text { Moderate } \\
\text { Months (L) }\end{array}$ & $\begin{array}{c}\text { Average Per } \\
\text { year (L) }\end{array}$ & $\begin{array}{c}\text { Annual Requirement } \\
(\mathrm{L})\end{array}$ \\
\hline Control & 288.0 & 105.0 & 213.0 & 200.0 & 70511.0 \\
\hline $5 \mathrm{~kg} /$ Tree & 279.36 & 101.85 & 206.61 & 194.0 & 68395.67 \\
\hline $10 \mathrm{~kg} /$ Tree & 270.72 & 97.65 & 200.22 & 188.0 & 66280.34 \\
\hline $15 \mathrm{~kg} /$ Tree & 264.384 & 96.6 & 194.895 & 184.0 & 64165.01 \\
\hline $20 \mathrm{~kg} /$ Tree & 259.2 & 94.5 & 191.7 & 180.0 & 63459.9 \\
\hline
\end{tabular}

While in Table (8) biochar addition to date palm trees grown in sandy soil improved soil properties and reducing irrigation water per tree from $70.49 \mathrm{~m}^{3} /$ tree per year to $56.39 \mathrm{~m}^{3} /$ tree per year. All 
treatments showed that increasing biochar percentage improved soil water retention above control.

Increasing the amounts of biochar increased the amounts of water saved and reduced the irrigation water requirements.

Table (5) Average irrigation water per date palm tree of 7 years old, during different seasons and water saved percent when using Biochar soil amendment in Al Ain for two years.

\begin{tabular}{|l|c|c|c|c|c|}
\hline \multirow{2}{*}{ Treatment } & \multicolumn{5}{|c|}{ Biochar } \\
\cline { 2 - 6 } & $\begin{array}{c}\text { Summer } \\
\text { months }(\mathrm{L})\end{array}$ & $\begin{array}{c}\text { Winter } \\
\text { months }(\mathrm{L})\end{array}$ & $\begin{array}{c}\text { Moderate Months } \\
(\mathrm{L})\end{array}$ & $\begin{array}{c}\text { Average Per } \\
\text { year }(\mathrm{L})\end{array}$ & $\begin{array}{c}\text { Annual } \\
\text { Requirement (L) }\end{array}$ \\
\hline Control & 281.0 & 103.0 & 214.0 & 197.0 & 70490.0 \\
\hline $5 \mathrm{~kg} /$ Tree & 264.14 & 96.82 & 201.16 & 185.18 & 66260.6 \\
\hline $10 \mathrm{~kg} /$ Tree & 257.958 & 94.039 & 196.88 & 180.846 & 64850.8 \\
\hline $15 \mathrm{~kg} /$ Tree & 236.883 & 86.52 & 179.974 & 165.874 & 59141.11 \\
\hline $20 \mathrm{~kg} /$ Tree & 229.015 & 82.4 & 171.2 & 156.615 & 56392 \\
\hline
\end{tabular}

Table (5). Depicts the effect of water saving products on reducing irrigation water for date palm tree grown in sandy soils. All treatments showed better results against control. Irrigation water required per tree has been reduced from $70.44 \mathrm{~m}^{3} /$ tree per year to $36.6 \mathrm{~m}^{3} /$ tree per year.

The results prove that water saver performed much better than biochar and biochar was better than compost, WS $>\mathrm{BC}>\mathrm{C}$ as in Tables (4-5-6).

Table (6) Average irrigation water per date palm tree of 7 years old, during different seasons and water saved percent in Al Ain for two years.

\begin{tabular}{|l|c|c|c|c|c|}
\hline \multirow{2}{*}{ Treatment } & \multicolumn{5}{|c|}{ Water saver } \\
\cline { 2 - 6 } & $\begin{array}{c}\text { Summer } \\
\text { months (L) }\end{array}$ & $\begin{array}{c}\text { Winter } \\
\text { months (L) }\end{array}$ & $\begin{array}{c}\text { Moderate } \\
\text { Months (L) }\end{array}$ & $\begin{array}{c}\text { Average Per year } \\
(\mathrm{L})\end{array}$ & $\begin{array}{c}\text { Annual } \\
\text { Requirement } \\
(\mathrm{L})\end{array}$ \\
\hline Control & 279 & 99 & 202 & 193 & 70440 \\
\hline $5 \mathrm{~kg} /$ Tree & 200.88 & 71.28 & 145.44 & 138.96 & 50716.8 \\
\hline $10 \mathrm{~kg} /$ Tree & 178.56 & 63.36 & 129.28 & 123.52 & 45081.6 \\
\hline $15 \mathrm{~kg} /$ Tree & 151 & 51 & 115 & 105.6 & 38540 \\
\hline $20 \mathrm{~kg} /$ Tree & 142.29 & 52.47 & 105.04 & 102.29 & 36628.8 \\
\hline
\end{tabular}


It is very clear that cultivating sandy soil consume huge amounts of irrigation water, due to its physical properties e.g. open structure and less organic matter content. (Russel1980 \& Wanjura, et al. 2002). Irrigation water requirements (m3/ha) after taking into account the proportion of cultivated area of date palm for each year were found to be $7044 \mathrm{~m} 3$ considering 100 trees per ha which mean, date palm tree consumed $70.44 \mathrm{~m}^{3} /$ tree under control while the percent water saved is $10 \%, 20 . \%$ and $48.0 \%$ when adding $20 \mathrm{~kg} /$ tree of compost, biochar and water saver respectively. The annual total irrigation water requirements $\left(\mathrm{m}^{3} /\right.$ tree) in different regions in KSA were, 95m3/tree, - $85 \mathrm{~m}^{3} /$ tree. Gafar (2010) in UAE stated that mature trees require $69.7 \mathrm{~m}^{3}$ pr year. Similar results obtained by (MOEW, 2015, Al Khalaf et al. 1998, Bruce \& Stanly , FAO, 2009, GAFAR, 2010 and Abdulrasoul, 2017).

The results recommend that for better management of irrigation water, farmers have to add soil amendments to reduce water losses and to improve the soil water retention and plant growth, (Wanjura, et al. 2002). The reason for soil amendment is to provide a better environment for roots and plant growth, this includes the improvement of the soil structure and water holding capacity, the availability of nutrients, and the living conditions for soil organisms, which are important for the plants to grow, (Xu et al. 2003, Wang et al. 2008 and Yazar et al. 2002) .

Biochar is used as a soil amendment to improve soil nutrient status, $\mathrm{C}$ storage and/or filtration of percolating soil water (Lehmaan \& Josef,, 2009). Biochar from pyrolysis and charcoal produced through natural burning share key characteristics including long residence time in soils and a soil conditioning effect (Glasser et al. 2002). Research has claimed that application of biochar can increase soil organic carbon (SOC), improve the supply of nutrients to plants and therefor enhance plant growth and soil's physical, chemical, and biological properties (Glaser et al. 2002) and Rondon et al. 2007).

Water saving amendments can alter soil physical properties such as structure, pore size distribution and density, with implications for soil aeration, water holding capacity, plant growth, and soil workability. Consequently this may improve soil water and nutrient retention (Dowine, et al. 2009). Biochar may increase the overall net soil surface area (Chan et al. 2007) reduce soil bulk density which is generally desirable for most plant growth (Brady and Weil 2004). Water saving 
amendments has a higher surface area and greater porosity relative to other types of soil organic matter, and can therefore improve soil texture and aggregation, which improves water retention in soil. Improved water holding capacity with biochar additions is most commonly observed in coarse-textured or sandy soils (Gaskin et al. 2009) and Glaser et al. 2002). Biochar has a higher sorption affinity for a range of organic and inorganic compounds, and higher nutrient retention ability compared to other forms of soil organic matter (Bucheli, et al.2000 and Bucheli and Gustafason 2003). and (Allen, et al., 2002, Kleineidam et al. 2002 and Nguyen et al. 2008).

Table (10) showed the periodical changes of WHC of sandy soil amended with compost. Results revealed that addition of compost increased WHC in all treatments over control, in the same time increasing the amounts of compost from $5 \mathrm{~kg} /$ tree till $20 \mathrm{~kg} /$ tree increased WHC for all treatments from 0.17 to 1.33 . that means WHC increased more than 7 times over control. While in table (11) showed addition of biochar to sandy soil increased WHC in all treatments above control. WHC of sandy soil amended with biochar increased from 0.17 to 3.37 , which means increased by 19 times. But for water saving product which is considered the highest water holding capacity material in this study, WHC increased from 0.17 to 8.73 which means increased by 51 times above control. Addition of compost organic fertilizer and biochar and water saver around the trees separately increased the WHC of the sandy soil (Table 2). But the addition of biochar increased the WHC of the soil doubly than addition of compost organic fertilizer, while addition of $20 \mathrm{~kg} /$ tree of water saver increased WHC more than 50 times of control and 2.6 times than compost and more than 6.56 times the compost treatments. The reported results are in line with several studies, (Badawi, 2019 b, Pokharel, 2020).

Table (7) Periodical changes of Water holding capacity (\%) in sandy soil amended with biochar through 180 days.

\begin{tabular}{|l|c|c|c|c|}
\hline \multirow{2}{*}{ Treatment } & \multicolumn{4}{|c|}{ Compost } \\
\cline { 2 - 5 } & 7 Days & 60 Days & 120 Days & 180 days \\
\hline Control & 0.17 & 0.16 & 0.16 & 0.16 \\
\hline $5 \mathrm{~kg} /$ Tree & 0.81 & 0.84 & 0.79 & 0.81 \\
\hline $10 \mathrm{~kg} /$ Tree & 0.90 & 0.94 & 0.91 & 0.89 \\
\hline $15 \mathrm{~kg} /$ Tree & 1.11 & 1.27 & 1.26 & 1.23 \\
\hline $20 \mathrm{~kg} /$ Tree & 1.33 & 1.30 & 1.31 & 1.17 \\
\hline
\end{tabular}


Table (8) Periodical changes of Water holding capacity (WHC\%) in sandy soil amended with biochar through 180 days.

\begin{tabular}{|l|c|c|c|c|}
\hline \multirow{2}{*}{ Treatment } & \multicolumn{4}{|c|}{ Biochar } \\
\cline { 2 - 5 } & 7 Days & 60 Days & 120 Days & 180 days \\
\hline Control & 0.17 & 0.16 & 0.16 & 0.16 \\
\hline $5 \mathrm{~kg} /$ Tree & 2.12 & 2.10 & 2.07 & 2.05 \\
\hline $10 \mathrm{~kg} /$ Tree & 2.65 & 2.67 & 2.60 & 2.53 \\
\hline $15 \mathrm{~kg} /$ Tree & 2.81 & 2.78 & 2.69 & 2.68 \\
\hline $20 \mathrm{~kg} /$ Tree & 3.37 & 3.30 & 3.19 & 3.17 \\
\hline
\end{tabular}

Table (8) depicted the water holding capacity of soil treated with biochar in comparison to control. All treatments received biochar showed water holding capacity improvement compared to control and increasing biochar content increased water holding content values (Katy et al. 2015 \& Glazonova et al. 2018).

Table (9) Periodical changes of Water holding capacity (WHC\%) in sandy soil amended with biochar through 180 days.

\begin{tabular}{|l|c|c|c|c|}
\hline \multirow{2}{*}{ Treatment } & \multicolumn{4}{|c|}{ Water saver } \\
\cline { 2 - 5 } & 7 Days & 60 Days & 120 Days & 180 days \\
\hline Control & 0.17 & 0.16 & 0.16 & 0.16 \\
\hline $5 \mathrm{~kg} /$ Tree & 5.12 & 5.10 & 5.07 & 5.05 \\
\hline $10 \mathrm{~kg} /$ Tree & 6.65 & 6.67 & 6.60 & 6.53 \\
\hline $15 \mathrm{~kg} /$ Tree & 7.81 & 7.78 & 7.69 & 7.68 \\
\hline $20 \mathrm{~kg} /$ Tree & 8.73 & 8.33 & 8.39 & 8.30 \\
\hline
\end{tabular}

At higher tensions close to wilting range, nearly all pores are filled with air and the moisture content is determined largely by the specific surface area and the thickness of water films on these surfaces. Sandy soils have much less surface area than clayey soils and, thus, retain much 
less water at higher tensions. However, with the addition of organic matter, and water saving products specific surface area increases resulting in increased WHC at higher tensions [Sohi et al. 2010 and Barrow 2012).

The application of biochar to soil offers multiple benefits in a wide range of agricultural systems. Biochar have been evaluated in various field crops and pastures around the world. Studies have found that biochar can improve plant yields, enhance soil water holding capacity and reduce fertilizer requirements, and results vary widely between different biochar, soil types, climates and target crops.

Compost, or decomposed organic matter, biochar and water saver has been found to enhance waterholding capacity improve soil structure. It further enhances the soil's water-holding capacity. It can help to retain more water in the soil during dry season. Farmers may also use and water saving amendments as soil to reduce evaporation, and infiltration of water (Cheng et al. 2006 \& Badawi, 2019a, b and Badawi, 2020)

The potential benefits of biochar soil amendment are well identified in the literature. These include carbon sequestration, improved crop yields, and enhanced water retention. The conversion of biomass carbon to biochar leads to sequestration of about $50 \%$ of the initial carbon compared to $3 \%$ sequestration from burning and less than $20 \%$ from biological decomposition (Chan et al. 2007) Biochar is resistant to decomposition and remains in the soil for centuries or millennia.

While many articles report on carbon sequestration potential and nutrient trapping, there have been only a few studies on the effect of biochar on water holding capacity. (Beat \& Suphler 2018) reported an increase in the water holding capacity of a loamy sand soil with $2 \%$ mixtures of biochar made from various switchgrass feedstocks. They were interested in understanding the different effects of temperature and feedstock on the water holding capacity of biochar but all values were calculated at a $2 \%$ mixture rate only. Another finding was an $11 \%$ increase in water holding capacity reported as an additional observation and was not validated through the use of control techniques (Dowine et al. 2009). The ability of biochar to increase water holding capacity could have profound effects on areas prone to drought. (Dowine et al. 2009), Sohi et al.2010) summarized the current state of biochar knowledge and concluded that soil water holding capacity was an area of significance that was lacking in research. 
Table (10) Periodical changes of Total Plate Counts, TPC content in sandy soil amended with compost through 180 days, $\mathrm{CFU} / 10^{6}$.

\begin{tabular}{|l|c|c|c|c|}
\hline \multirow{2}{*}{ Treatment } & \multicolumn{4}{|c|}{ Compost } \\
\cline { 2 - 5 } & 7 Days & 60 Days & 120 Days & 180 days \\
\hline Control & 31.9 & 34.1 & 36.2 & 32.3 \\
\hline $5 \mathrm{~kg} /$ Tree & 69.3 & 71.2 & 88.1 & 74.3 \\
\hline $10 \mathrm{~kg} /$ Tree & 84.0 & 91.0 & 92.3 & 89.0 \\
\hline $15 \mathrm{~kg} /$ Tree & 88.0 & 98.5 & 99.1 & 99.4 \\
\hline $20 \mathrm{~kg} /$ Tree & 93.7 & 103.0 & 107.0 & 107.8 \\
\hline
\end{tabular}

Table (11) Periodical changes of Total Plate Counts, TPC content in sandy soil amended with biochar through 180 days, CFU/10 $0^{6}$.

\begin{tabular}{|l|c|c|c|c|}
\hline \multirow{2}{*}{ Treatment } & \multicolumn{4}{|c|}{ Biochar } \\
\cline { 2 - 5 } & 7 Days & 60 Days & 120 Days & 180 days \\
\hline Control & 31.0 & 32.0 & 33.0 & 32.0 \\
\hline $5 \mathrm{~kg} /$ Tree & 68.0 & 67.2 & 88.1 & 74.3 \\
\hline $10 \mathrm{~kg} /$ Tree & 84.0 & 88.0 & 92.3 & 89.0 \\
\hline $15 \mathrm{~kg} /$ Tree & 87.0 & 96.5 & 98.1 & 99.4 \\
\hline $20 \mathrm{~kg} /$ Tree & 91.7 & 101.0 & 102.0 & 100.8 \\
\hline
\end{tabular}

Table (12) Periodical changes of Total Plate Counts, TPC content in sandy soil amended with water saver through 180 days, CFU/106.

\begin{tabular}{|l|c|c|c|c|}
\hline \multirow{2}{*}{ Treatment } & \multicolumn{4}{|c|}{ Water saver } \\
\cline { 2 - 5 } & 7 Days & 60 Days & 120 Days & 180 days \\
\hline Control & 32.9 & 33.0 & 33.4 & 32.6 \\
\hline $5 \mathrm{~kg} /$ Tree & 69.0 & 71.2 & 78.1 & 74.3 \\
\hline $10 \mathrm{~kg} /$ Tree & 86.0 & 98.0 & 94.3 & 89.0 \\
\hline $15 \mathrm{~kg} /$ Tree & 89.0 & 96.5 & 98.8 & 101.4 \\
\hline
\end{tabular}




\begin{tabular}{|l|l|l|l|l|}
\hline $20 \mathrm{~kg} /$ Tree & 91.7 & 101.0 & 105.0 & 103.8 \\
\hline
\end{tabular}

Table (13) Periodical changes of Total fungi colonies content in sandy soil amended with compost through 180 days, CFU/10 4 .

\begin{tabular}{|l|c|c|c|c|}
\hline \multirow{2}{*}{ Treatment } & \multicolumn{4}{|c|}{ Compost } \\
\cline { 2 - 5 } & 7 Days & 60 Days & 120 Days & 180 days \\
\hline Control & 7.90 & 7.99 & 7.31 & 7.28 \\
\hline $5 \mathrm{~kg} /$ Tree & 13.10 & 13.90 & 14.20 & 13.10 \\
\hline $10 \mathrm{~kg} /$ Tree & 14.60 & 16.20 & 17.20 & 17.00 \\
\hline $15 \mathrm{~kg} /$ Tree & 16.00 & 17.40 & 19.90 & 19.00 \\
\hline $20 \mathrm{~kg} /$ Tree & 18.80 & 19.20 & 19.90 & 21.00 \\
\hline
\end{tabular}

Table (14) Periodical changes of Total fungi colonies content in sandy soil amended with biochar through 180 days, CFU/10 4 .

\begin{tabular}{|l|c|c|c|c|}
\hline \multirow{2}{*}{ Treatment } & \multicolumn{4}{|c|}{ Biochar } \\
\cline { 2 - 5 } & 7 Days & 60 Days & 120 Days & 180 days \\
\hline Control & 7.20 & 7.29 & 7.31 & 7.28 \\
\hline $5 \mathrm{~kg} /$ Tree & 12.10 & 12.90 & 13.20 & 13.90 \\
\hline $10 \mathrm{~kg} /$ Tree & 14.30 & 16.10 & 17.20 & 17.00 \\
\hline $15 \mathrm{~kg} /$ Tree & 16.00 & 17.40 & 18.60 & 19.00 \\
\hline $20 \mathrm{~kg} /$ Tree & 18.30 & 19.20 & 19.40 & 20.00 \\
\hline
\end{tabular}

Table (15) Periodical changes of Total fungi colonies content in sandy soil amended with water saver through 180 days, CFU/10 4

\begin{tabular}{|l|c|c|c|c|}
\hline \multirow{2}{*}{ Treatment } & \multicolumn{4}{|c|}{ Water saver } \\
\cline { 2 - 5 } & 7 Days & 60 Days & 120 Days & 180 days \\
\hline Control & 7.16 & 7.29 & 7.30 & 7.28 \\
\hline $5 \mathrm{~kg} /$ Tree & 14.10 & 14.90 & 14.20 & 13.90 \\
\hline $10 \mathrm{~kg} /$ Tree & 16.30 & 16.80 & 17.20 & 17.10 \\
\hline $15 \mathrm{~kg} /$ Tree & 17.00 & 17.40 & 18.90 & 19.00 \\
\hline
\end{tabular}




\begin{tabular}{|l|l|l|l|l|}
\hline $20 \mathrm{~kg} /$ Tree & 18.30 & 19.90 & 19.40 & 21.40 \\
\hline
\end{tabular}

Table (10-11-12) describe the total bacterial population measured by plate count technique in the soil amended with different rates of water saving products Compost, biochar and water saver from $5 \mathrm{~kg} /$ tree till $20 \mathrm{~kg} /$ tree. Numbers of CFU increased with increasing dose of compost, biochar and water saver applied in all treatments. All treatments showed high microbial counts over control. Bacterial population was in the range of 31-32 millions bacteria in the control treatment while increased sharply in all treatments reaching $10^{7}$ millions of CFU/gram for compost treated sandy soil while in case of biochar the numbers were in the range of 100 millions of CFU, while in water saver treatments bacterial numbers reached $10^{3}$ millions microbes after 180 days.

Microbial biomass and total plate counts in most cases increases in the presence of biochar. Notable exceptions are mycorrhizae in situations of abundant nutrient supply. No direct negative effects of biochars on roots have been detected. Critical to further advances is the recognition and reporting of the diversity of biochars. (Lehmaan, et al. 2011, and Pokharel et al. 2020).

Fungi population are depicted in Tables (13-14-15) the total fungi colonies showed less numbers, e.g. control treatments showed $7 \times 10^{4}$, while for treatments received compost, biochar, and water saver the fungi numbers grown in the range of 20-21 X10 $\mathrm{CFU} / \mathrm{gram}$ of soil received compost, biochar and water saver respectively. . The significant differences in bacteria, and fungi population were observed between biochar and control (Lehmaan et al. 2011 Rolf and Bakken (1987) and Adel et al. 2015).

The microscopic structure of,compost biochar and water saver is one of the primary determinants in its soil conditioning properties; the surface area of the pre-charred source material can be increased several thousand fold (Wang 2008).

The water retained in sandy soil by the water saver product was higher than Biochar and compost organic fertilizer. Therefore addition of soil amendments in date palm tree sandy lands increases the WHC of the soil. This addition enhance plant growth and improve water use efficiency. Surface area and organic matter percentage influences in the water-holding capacity. As the percentage increases, the water-holding capacity increases because of the affinity of organic matter has for 
water (Vengadaramana, A. \& Jashothan, 2012 and Yuan et al. 2001 and Christopher and Michael 2018).

Much of this interest is focused on water saving amendments. The claims for them are many: larger crop yields, decreased fertilizer requirements, greater microbial activity, reductions in greenhouse gas emissions from fields, greater soil water holding capacity, drought mitigation, and increased soil organic carbon content (SOC), which can improve the physical properties of soil. Further, carbon sequestration benefits of biochar soil amendment have been heavily studied (Lehmaan, 2007 and Liang et al. 2006 and Badawi, 2019 a ), while (Sohi et al 2010) . showed that soils with a high water holding capacity produce increased crop yields and a decreased need for irrigation. (Singh et al. 2010) \& (Glaser, 2002) suggested that the increased porosity of biochar increases water retention in soils, and the enhancement depends on biochar feedstock, soil type, and mixture rates. Nutrients dissolved in the water may also be retained in the soil so plants may be better able to access the nutrients (Yuan et al. 2001).

\section{Economics of using irrigation water saving amendments:}

Table (16) Evaluation of water saving amendments on economics of water consumption on date palm plantation, using $15 \mathrm{~kg}$ per tree under UAE water tariff of $0.85 \$ / \mathrm{m}^{3}$.

\begin{tabular}{|l|c|c|c|c|}
\hline Product & $\begin{array}{c}\text { Material unit } \\
\text { cost, }(\$ / \mathrm{kg})\end{array}$ & $\begin{array}{c}\text { Material cost } \\
(\$ / 15 \mathrm{~kg})\end{array}$ & $\begin{array}{c}\text { Water saved } \\
\left(\mathrm{M}^{3} / \text { tree/year }\right)\end{array}$ & $\begin{array}{c}\text { Total money } \\
\text { Saved in }(\$) / \text { tree / year }\end{array}$ \\
\hline Compost & 0.110 & 1.65 & 6.35 & 5.40 \\
\hline Biochar & 0.380 & 5.70 & 11.35 & 9.65 \\
\hline Water saver & 1.600 & 24.00 & 31.90 & 27.13 \\
\hline
\end{tabular}

Water saving amendments was calculated at $15 \mathrm{~kg} /$ tree and water price a per UAE Agriculture tariff, (subsidized price).

When we add $15 \mathrm{~kg} /$ tree of different water saving amendments, we found that compost can save $6.35 \mathrm{~m}^{3} /$ tree of water per year, while adding $15 \mathrm{~kg}$ of biochar it can save $11.35 \mathrm{~m}^{3} /$ tree of water per year, while using the water saver product, we can save $31.90 \mathrm{~m}^{3}$ of water/tree per year, if we calculate how much money we can save when we use water saving amendments materials it can be as follow, compost can save $5.40 \$$, followed by biochar can save $9.65 \$$ per tree per year while water saver product can save $27.13 \$$ per tree per year. To reflect these water saving we can save huge amounts of water on the global basis or at least for Arab countries which have 105 millions 
of date palm trees. Along with these irrigation water saving, soil physical, chemical and biological properties are improved.

To promote the practice of agricultural soil water saving amendments, the full life cycle costs and benefits to soil amendment must be estimated. The effect of water holding capacity on crop growth due to water holding capacity, nutrient retention, and microbial growth must be understood, in addition to the benefits of the likely reduced need for irrigation and fertilizer and pesticide usage. Inclusion of traditionally externalized costs associated with carbon and environmental degradation, a side effect of current farming and irrigation techniques, will further improve the cost/benefit analysis of agricultural water saving amendments usage.

\section{CONCLUSION}

Proper water management in sandy soil should use available organic matter in their farms to be serving as soil conditioner and to act for saving water for better plant growth and soil microbial activities in the soils.

Addition of water saving amendments improved water retention and contribute to: $\bullet$ improved crop yields, produces uniform moisture at the root zone, reduces irrigation requirement by up to $50 \%$, saving both water and money, reduces evapotranspiration, holding water and nutrients at the roots to produce strong, healthy plants. Sandy soils to retain water and nutrients. We can save more than $40 \%$ of irrigation water requested for date palm plantation. This water saving can be used for other eventual needs of water e.g. industry and other purposes.

To promote the use of compost, biochar and water saver as soil amendment, it is important to understand the mechanism of the amended water retention, to characterize the effects of feedstock, biochar production, soil types, and mixtures, and to quantify these effects on plant growth. 


\section{REFERENCES}

A.O.A.C. 1975. Association of official analytical chemists. Official methods of analysis 12 th Ed A.O.A.C. Washington DC USA.

Abdulrasoul A., Al-Shemeri , F. Samir E., and Mahmoud N., 2017. Determination of date palm water requirements in Saudi Arabia.

Adel, R.A., Usmana B., Adel A., Meththika V., Yong S. Oke, M. Ahmada, M. A., Elfakia, J. S. S. Abdulazeema,M. \& Al-Wabela,I 2015 Biochar production from date palm waste: Charring temperature induced changes in composition and surface chemistry, J. Analytical and applied pyrolysis V(15) 392-400.

Ag-Irrigation Management, 2000 Irrigation Training and Research Center.

Ahmad T., Danish M., Rafatullah M., Ghazali A., Sulaiman O., Hashim R., \& Ibrahim M. N. M., 2012. The use of date palm as a potential adsorbent for wastewater treatment: a review. Environ Sci Pollut Res Int, 19(5), 1464-1484. doi: 10.1007/s11356-011-0709-8

Al Khafaf S. Al Shiraqui R., and Shabana H., 1998; "Irrigation scheduling of palm trees in UAE"; the 1st international conference on date palms, UAE University; Faculty of agricultural science.

Allen R.G., Pereio L.S., Raes D., and Smith M., 1998. FAO Irrigation and drainage paper No. 56, Rome; "Crop evapotranspiration: Guidelines for computing crop requirements".

Badawi, M A. 2020. Date Palm Trees Fertilization Requirements and Its Effect on Dates Yield, (Chapter 3 Date Palm: Composition, Cultivation and Uses, 36 pp. Beltane Bolduc (Editor) Series: 
Plant Science Research and Practices, BISAC: SCI073000 ISBN: 978-1-53616-676-7Categories: Nova, 2020, Plant Science Research and Practices

Badawi, M. A. 2019 (a). Production of Biochar from Date Palm Fronds and its effects on soil properties. By-Products of Palm Trees and Their Applications Materials Research Forum LLC, Materials Research Proceedings 11, 159-168.

Badawi, M. A., 2019 (b). Water Saver is a Natural Product for Saving Irrigation Water in Date Palm and Golf Course Plantations in UAE, Journal of Agriculture Food and Development, 2019, 5, 57-62 57. E-ISSN: 2415-0142/19 @ 2019 Journal of Agriculture Food and Development

Barrow C.J., 2012. Biochar: Potential for countering land degradation and for improving agriculture. Applied geography, 34, 21-28.

Beat S., Spuhler N. C. D. 2018. Soil amendment. Ag-Irrigation management (Irrigation training and research center, 2000)

Black C.A. Evans; O.D. Ensminger L.E., White J.L., Clark F.E., and Dinaver R.C., 1982. Methods of soil analysis part II. Chemical and microbiological properties, 2nd, Soil Sci., socities of Am. Inc., publications madison wisconsin, USA, pp, 1573.

Blake, G.R. and Hartge, K.H. 1986. Bulk density. Methods of Soil Analysis, Part 1, 2nd edition, pp: 363-376. Physical and Mineralogical Methods, Agronomy Monograph No. 9, Madison, WI, USA

BradyN.C \& Weil,R.R. 2004 Biochar Manual for Small Farms in BC, Digital copy available at: https://sites.google.com/site/fcfcbiocharmanual

Brady, N.C. \& Weil, R. R T.1998. The nature and properties of soils, Macmillan: New York, 2014. Bruce W. \& Stanley V. Book, IRRIGATION: DESIGN AND PRACTICE". 
Bucheli, T.D., Gustafsson, O. 2000. Quantification of the soot-water distribution coefficient of PAHs provides mechanistic basis for enhanced sorption observations. Environ. Sci.Technol. 34:5144-5151.

Chapman, H.D. 1965. Cation-exchange capacity. In: C.A. Black (ed.). Methods of soil

Champan H.D., and Pratt P.F., 1961. Methods of analysis for soils, plants and water. univ. of california davis. Div. of Agric. Science.

Chan K., Van Zwieten L., Meszaros I., Downie A., Joseph S.,:2008. Agronomic values of green waste biochar as a soil amendment. Soil research, 45(8):629-634.

Cheng, C.-H. J. Lehmann, and M. H. Engelhard. 2008. Natural oxidation of black carbon in soils: Changes in molecular form and surface charge along a climosequence. Geochim.Cosmochim. Acta 72: $1598-1610$.

Cheng, C.-H., J. Lehmann, J.E. Thies, S.D. Burton and M.H. Engelhard. 2006. Oxidation of black carbon by biotic and abiotic processes. Organic Geochemistry. 37:1477-1488.

Christopher W.S., and Michael K., 2018 Effects on soil water holding capacity and soil water retention resulting from soil health management practices implementation- A review of the literature posted to the NRCS Soil health website as of 9/2016.

Claoston, N., Samsuri, A. W., Ahmad Husni, M. H., \& Mohd Amran, M. S., 2014. Effects of pyrolysis temperature on the physicochemical properties of empty fruit bunch and rice husk biochars. Waste Manag Res, 32(4), 331-339. doi: 10.1177/0734242X14525822

Difco manual, 1985. Dehydrated culture media and reagents for microbiology, laboratories incorporated, Detroite, Mitchigan, 48232, USA, 621.

Donnelly K. and Cooley H. 2015. Water Use Trends in the United States, Pacific institute, publications $16 \mathrm{pp}$. 
Doorenbos J., and Kassam A.H., 1977, FAO Irrigation and drainage paper No.24, Rome, Guidelines for predicating crop water requirements".

Downie, A., A. Crosky and P. Munroe 2009. Physical properties of biochar. In Biochar for environmental management: science and technology Eds. J. Lehmann and S. Joseph. Earthscan, London; Sterling, VA, pp. 13-32.

FAO (Food and agriculture organization of the United Nations)., 2012. Statistical databases. Downloaded from http://faostat.fao.org.

FAO, (Food and agriculture organization of the United Nations) 2009 Water report 34, 2009: UAE. Agriculture organization of the unitednations, and world health organization Rome, Italy.

Gafar K.Y., 2010, Water requirements for date palm trees in Al ain, AD United Arab Emirates, Al Shagarah Al Mubarakah, (The Blesses Tree) Sept, 2010, Arabic.

Gaskin J.W., Das, K.C. Tassistro, A.S. Sonon,L. Harris, K. Hawkins, B. 2009, Characterization of char for agricultural use in the soils of the southeastern United States, in: W.I. Woods (Ed.), Amazonian Dark Earths: Wim Sombroek's Vision\|, Springer Science, Business Media, Heidelberg, Germany, p.p. 433-443.

Glaser B., Lehmann J., Zech W., 2002. Ameliorating physical and chemical properties of highly weathered soils in the tropics with charcoal - a review. Biology and fertility of soils.35:219-230.

Glazunova, D.M. Kuryntseva, P. S Y Selivanovskaya, S.Y. Galitskaya, P.Y. 2018. Assessing the Potential of Using Biochar as a Soil Conditioner, 107(1):012059 .

Hansen V.E., Israelesen O.W., Stringham G.E., 1979, "Irrigation principles and practices", Forth edition. Utah state univercity, Logan,Utah. 
Karhu K., Mattila T., Bergström I., Regina K.2011. ,: Biochar addition to agricultural soil increased CH4 uptake and water holding capacity - results from a short-term pilot field study. Agr Ecosyst environ, 140(1):309-313.

Katy E.B., Brye K.R., Mary C., Savin, and Longer D.M., 2015 Biochar source and application rate effects on soil water retention determined using wetting curves, Open journal of soil science, 2015, $5,1-10$

Khanmohammadi, Z., Afyuni, M., \& Mosaddeghi, M. R., 2015. Effect of pyrolysis temperature on chemical and physical properties of sewage sludge biochar. Waste Management \& Research, 33(3), 275-283. doi: 10.1177/0734242X14565210

Kleineidam, S., Schuth, C., and Grathwohl, P. 2002. Solubilitynormalized combined adsorptionpartitioning sorption isotherms for organic pollutants. Environ. Sci. Technol. 21:4689-4697.

Kristian P., Olsen S.M., Shehata A., Bondok, Shereen M., El Nahrawy A.Y., ElKerdany, 2016. Response of egyptian clover to nano clay flakes in newly reclaimed sandy soils under sprinkler irrigation system. J. Alexandria Sci., Exchange. Vol., 37.No. 4. October- December, 2016.

Lehmann J., Gaunt J., Rondon M.,2009. Biochar sequestration in terrestrial ecosystems - a review. Mitigation and adaptation strategies for global change. 2006, 11(2):395-419.

Lehmann J., Joseph S.2009. Biochar for environmental management: Science and technology. London: Earthscan/James \& James; 2009.

Lehmann J., Rillig M.C., Thies J., Masiello C.A., Hockaday W.C., \& Crowley D., 2011, September. Biochar effects on soil biota - A review. Soil biology and biochemistry, 43(9), 18121836. Retrieved October 11, 2013 
Liang B., Lehmann J., Solomon D., Kinyangi J., Grossman J., O’Neill B., Skjemstad J.O., Thies J., Luizao F.J., Petersen J., and Neves E.G., 2006. Black carbon increases cation exchange capacity in soils. Soil science society america journal, vol 70, pp1719-1730.

Liang, B., Lehmann, J., Solomon,D., Kinyangi, J., Grossman, J., O’Neill, B., Skjemstad, J.O., Thies, J., Luizao, F. J., Petersen, J. and Neves, E. G. 2006. Black carbon increases cation exchange capacity in soils. Soil Science Society America Journal, vol 70, pp1719-1730.

MOEW, 2015 Ministry and environment and water, UAE State of environment report.

Muhamed T.A., Lopez B., C.G. Lina Y., and Shmidt J.E., 2018. Economic analysis of biochar production from date palm fronds. I Energy, MASDAR institute of science and technology, PO Box 54224, AD, UAE.

Nguyen, B. T., Lehmann, J., Kinyangi, J., Smernik, R., Riha, S. J., and Engelhard, M. H.2008. Long-term black carbon dynamics in cultivated soil. Biogeochemistry 89:295- 308.

Novak JM., Busscher WJ., Laird DL., Ahmedna M., Watts DW., Niandou MAS: Impact of biochar amendment on fertility of a southeastern coastal plain soil. Soil Sci 2009, 174(2):105-112. 10.1097/SS.0b013e3181981d9a

Olness A. and David A. 2005. Effect of Organic Carbon on Available Water in Soil, Soil science, 170 (2). 90-101.

Pokharel, P. Ma, Z. Chang S.X., 2020 Biochar increases soil microbial biomass with changes in extra- and intracellular enzyme activities: a global meta-analysis, Biochar, (2) 65-79.

properties as indicators of soil physical quality. Soil Sci., 172:

Qasim H., Alwan* A. Mohammed R. Mohanned H. S. Zainab H. Ali, A. Abdul Satar A. Shaker J. A. 2015. Characterization of biochar produced from IRAQI Palm fronds by thermal pyrolysis Al-Khwarizmi engineering journal,Vol. 11, No. 2, P.P. 92-102. 
Rolf A.O., and Bakken L.R., 1987. Viability of soil bacteria: optimization of plate counting technique and comparison between total counts and plate counts within different size groups. Micro. Ecol., 13: 59-74.

Rondon, M. A., Lehmann, J. Ramirez, J. Hurtado. M. 2007. Biological nitrogen fixation by common beans (Phaseolus vulgaris L.) increases with bio-char additions. Biology and fertility of soils 43:699-708.

Russel E.W., 1980. Soil conditions and plant growth 10th, Longman, London and New York. Singh B., Singh BP., Cowie A.L., 2010. Characterisation and evaluation of biochars for their application as a soil amendment. Soil research 2010, 48(7):516-525. 10.1071/SR10058

Sohi S.P., Krull E., Lopez-Capel E., and Bol R., 2010. A review of biochar and its use and function in soil Pages 47-82 Advances in agronomy, Vol 105. Advances in agronomy. San Diego, Elsevier academic press inc.

Vengadaramana A., and Jashosan, A. 2012. Effect of organic fertilizers on the water holding capacity of soil in different terrains of Jaffna peninsula in Sri Lanka. J. Nat. Prod. Plant Resour., 2012, 2 (4):500-503 - ISSN : 2231 - 3184

Wallace J. 2000. Increasing agricultural water use efficiency to meet future food production. Agr Ecosyst environ, 82(1-3):105-119.

Wan, S.Q., Kang, Y.H., Wang, D., Liu, S., Feng, L.P., 2007. Effect of drip irrigation with saline water on tomato (Lycopersicon esculentum Mill) yield and water use in semi-humid area. Agric. Water Manage. 90, 63-74.

Wang, Y., Xiao, D., Li, Y., Li, X., 2008. Soil salinity evolution and its relationship with dynamics of groundwater in the oasis of inland river basins: case studyfrom the Fubei region of Xinjiang Province. China Environ. Monit. Assess. 140,291-302. 
Wanjura, D.F., Upchurch, D.R., Mahan, J.R., Burke, J.J., 2002. Cotton yield andapplied water relationships under drip irrigation. Agric. Water Manage. 55,217-237

Warnock D.D., Lehmann J., Kuyper T.W., Rillig M.C.,: Mycorrhizal responses to biochar in soil concepts and mechanisms. Plant Soil 2007, 300(1-2):9-20.

WHO, 2010, Expert meeting on the application of nanotechnologies in the food and agriculture sectors: potential food safety implications, food and agriculture organization of the united nations, and world health organization Rome, Italy.

Yazar, A., Sezen, S.M., Sesveren, S., 2002. LEPA and trickle irrigation of cotton in the Southeast Anatolia Project (GAP) area in Turkey. Agric. Water Manage. 54 (3),189-203

Yu O., Raichle B., \& Sink S.,2013. Impact of biochar on the water holding capacity of loamy sand soil. Int J Energy Environ Eng 4, 44 (2013). https://doi.org/10.1186/2251-6832-4-44

Yuan, J., Xu, R., \& Zhang, H., 2011. The forms of alkalis in the biochar produced from crop residues at different temperatures. Bioresource Technology, 102(3), 3488-3497. doi:10.1016/j.biortech.2010.11.018

Zaid A., 2005, FAO, 156., Production and protection of date palm trees paper, No.: 156.

Zainab M., El Hanandeh A., and Yu Q.J., 2015. Date palm (Phoenix Dactylifera L.) Seed characterization for biochar preparation, Journal of analytical and applied pyrolysis 115 (2015) $392-400$

Zhang, Y., W. Zhao, L. Fu., (2017) Soil macropore characteristics following conversion of native desert soils to irrigated croplands in a desert-oasis ecotone, Northwest China, Soil Tillage Res., 168 (2017), pp. 176-186 
توفير مياه الرى فى مزارع النخيل بإستعمال المواد الطبيعية الحافظة والموفرة للمياه

محمد على بلوى

معهد بحوث الأراضى والمياه والبيئة ، مركز البحوث الزراعية ، الجيزة مصر

مدير عام ، مصنع الإمارات للأسمدة البيولوجية

\section{dr_badawi22@hotmail.com}

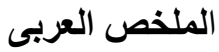

يتحمل نخيل التمر ظروف مناخية ونربة قاسية نسبيًا في الدول العربية. وتتر اوح الإحتياجات السنوية لمياه الري للنخلة في المنطقة العربية بين 73.0 إلى 95 (م 3 / شجرة). ويستخدم ما يقرب من 70 في المائة من الموارد المائية للمياه العذبة في القطاع الزر اعي ، و على الرغم أن كفاءة إستخدام المياه في العديد من البلدان العربية تقل عن 50 في المائة. وتحتاج التحول لطرق رى حديثة ومستدامة و فى هذه التجربة إستعملنا مو اد طبيعية لتوفير مياه الرى ، وهي خلطات طبيعية من مواد متاحة فى المزرعة من التربة ومخلفات تقليم النخيل يتم تطوير ها ومعالجتها و إستخدامها لتقليل كمية المياه اللازمة للري لمز ارع نخيل التمر ، وللحفاظ على نمو النباتات و الأشجار بحالة جيدة. و عند مزج هذه المواد حول المجموع الجذرى في التربة ، يمكن أن تحتفظ المادة بكميات كبيرة من الماء لكل كجم على سبيل المثال 3 و 5 و 25 لتر/كجم من المنتج - كمبوست - بيوتنثار - ووتر سيفر على الترتيب. و عندما تجف التربة سيطلق المنتج مياهه إلى النبات. وتعمل المواد الوفرة لمياه الرى و الحافظة للمياه على توفير المياه وتخزينها و منعها من الفقد، حتى أثناء فترات الجفاف فإنه يتم إطلاق المياه المخزنة إلى النباتات. و لا يقتصر إستخدام مو اد الحافظة للمياه على توفير المياه فحسب ، بل يؤدي أيضًا إلى تحسين الخصائص الفيزيائية للتربة مثل تحسين قدرة الإحتفاظ بالماء (WHC) وقدرة التبادل الكاتيوني (CEC) للتربة المعالجة. في هذه التجربة إستخدمنا ثلاث مو اد طبيعية مختلفة للمحافظة على المياه لدر اسة تأثثير ها على توفير مياه الري تحت مز ارع نخيل التمر فى دولة الإمار ات. تم استخدام ثلاث مو اد مختلفة لتوفير المياه ، مثل ال

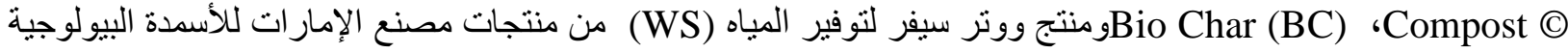
على أربعة مستويات مختلفة على سبيل المثال الكنترول و 5 كج و كج10 و 15 كج و 20 كجم لكل شجرة نخيل عمرها 7 هابل سنو ات مزرو عة في محطة أبحاث السلامات ، العين الإمار ات العربية المتحدة. و التى تضاف لمرة واحدة وتبقى فعالة فى التربة لسنو ات عديدة. وتم إستخدام منتجات توفير المياه لدر اسة أثر ها فى توفير المياه في التربة الرملية لمزارع النخيل في دولة الإمار ات العربية المتحدة. وإستمرت الدراسة لمدة عاميين منتاليين 2016/2017 وكذلك 2018/2017 ونم تقييم النتائج بعد عامين من الإختبار ، وجدنا أن إضافة مواد توفير المياه يمكن أن توفر أكثر من 45٪ من مياه الري لأشجار النخيل. أوصت النتائج بأن إضافة 15 كجم / شجرة النخيل يمكن أن يقلل من المياه اللازمة للري بنسبة 45 ٪. وفي هذه الدراسة ، ركزنا بشكل أساسي على إدخال وسيلة طبيعية لإدارة مياه الري من خلال تحسيين و إصلاح التربة ، بإستخدام مو اد توفير المياه لخلطها في التربة حول الأشجار لمنع فقدان المياه عن طريق التبخر والتسرب وتحسين خصائص التربة الفيزيائية والكيميائية و البيولوجية. تمت در اسة المردود و العائد الإقتصادي لقيمة لمياه الموفرة ووجدنا أنه يمكن توفير ماقيمته 27 دو لار فى العام عند إضافة 15 كج للنخلة من مادة الووتر سيفر بينما يمكن توفير 5 دولارات لكل نخلة عند إستعمال 15 كج كمبوست أما فى حالة البيوتشار يمكن توفير 9.6 دو لار مياه رى لكل شجرة عند إستعمال 15 كج من البيونتشار. الكلمات الرئيسية: الكمبوست - البيوتشار - الووتر سيفر - رى أشجار النخيل ـ المواد الحافظة لمياه الرى. 